DOI https://doi.org/10.18551/rjoas.2018-03.09

\title{
MEASUREMENT FOR ACCEPTANCE OF SUPPLY CHAIN SIMULATOR APPLICATION USING TECHNOLOGY ACCEPTANCE MODEL
}

\author{
Erna Mulyati* \\ Diploma IV Program of Business Logistics, Politeknik Pos Indonesia, Bandung, Indonesia \\ Dini Hamidin, Mohamad Nurkamal Fauzan \\ Department of Informatic Engineering, Politeknik Pos Indonesia, Bandung, Indonesia \\ ${ }^{*}$ E-mail: rna rian@yahoo.com
}

\begin{abstract}
The aim of this research for was to measure the user acceptance of simulator application which was built as a tool for student in learning of supply chain, particularly in bullwhip effect problem. The measurements used for the acceptance of supply chain simulator application in this research was the Technology Acceptance Model from 162 samples which were analyzed with Confirmatory Factor Analysis and Structural Equation Modelling. The result of this research indicated that the user acceptance (shown by customer participation) of supply chain simulator was directly influence by perceived usefulness of supply chain simulator application used (positive and significant); the user acceptance of supply chain simulator was indirectly influenced by perceived ease of use in using supply chain simulator application (positive but not significant); the user acceptance of supply chain simulator was indirectly influenced by perceived enjoyment when the supply chain simulator application was used. The research would give a better understanding about a bullwhip effect and better experience for students, which would not be obtained through conventional learning, when the tools were not used.
\end{abstract}

\section{KEY WORDS}

Supply chain, bullwhip effect, simulator, simulation.

In the education system, teachers are key to the effective use of technology in teaching and learning process. The use of technology also is very helping students as a means to improve the learning process quality and increase the competence of human resource. Beer game is a game which is used as a mean of simulation game from course of logistic and supply chain. This game is given to the student which will later on brings experience in industry area to the students in managing distribution planning of goods from one manufacturer to the retails or the end user (customers), as well as the understanding of the impact of "bullwhip effect" in the supply chain area.

The bullwhip effect is a condition which should be avoided because it will give an impact on high cost of industrial logistic process in upstream and downstream relationships. Above user experience obtained from the game would give an experience to human resources in logistic field in order to avoid and to solve the problems which may happend in the real world when they work in industry field.

The development of information technology, particularly the game with simulator model has become a trend which is mostly used in order to increase user experience in supply chain relationship. The application of supply chain simulator is an application which is build as a tool in learning of supply chain, particularly bullwhip effect. The problem in the research are as follows: how to identify the realted user experience variables in the implementation of the aplication of supply chain simulator; how the user experience on supply chain simulator; how difference the application of supply chain simulator if compaired with the related user experience conventional method.

Based on above mentioned problems, then the research was carried to measure the user experience of supply chain simulator using TAM. 
Application of Supply Chain Simulator. The model of supply chain simulator which is implemented into the application of supplu chain simulator. In this research is facilitated with the following features and services: supply chain applies only as retailer - wholesaler distributor - factory in one chain; the game is one group can only be played by a minimum of 2 to a maximum of 4 people with different roles; the application is provided with EOQ method calculation and forecasting (only 1 method); the game is customized in week number (set 12 weeks, 30 seconds per week) or set 52 weeks -52 minutes; the role scenario is determined by administrator as game facilitator; Based on the feature which are implemented in the application of supply chain simulator, then the architecture system in the following application of supply chain simulator:

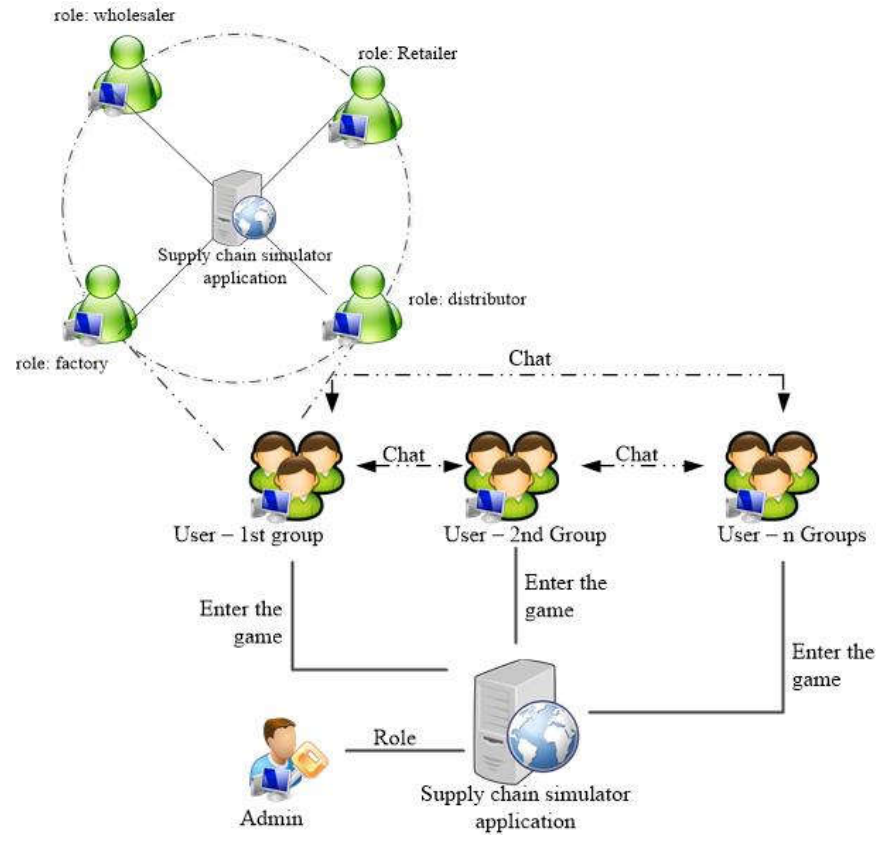

Figure 1 - Architecture system in the application of supply chain simulator

Method of Accepatence Measurement Application supply chain simulator

This measurement method is part of the simulator application testing series of supply chain application simulator with the following method:

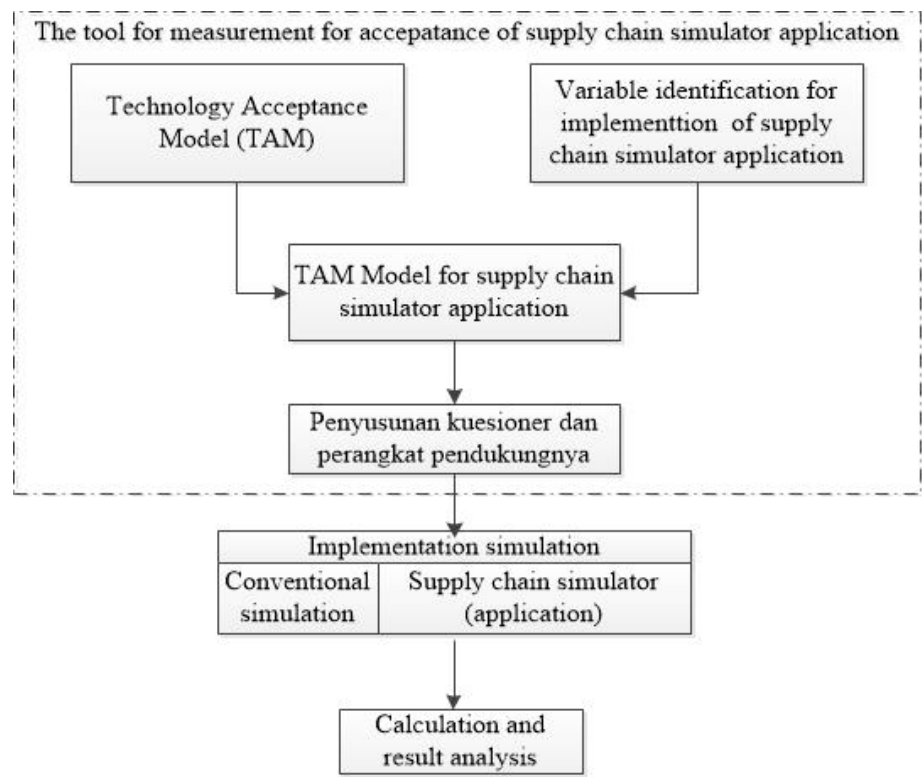

Figure 2 - Acceptance Measurement Method of Supply Chain Simulator Application 
Analysis of TAM theory and variable identification were used to identify the TAM model which was suitable with the simulator application of supply chain.

TAM model of the simulator application supply chain was used as the reference of established questionnaires which were used as the benchmarks of application acceptance of supply chain simulator.

Implementation of simulation was divided into 2 parts, i.e. implementation of conventional simulation with observation, while SEM was used for the measurement implementation of simulator application of supply chain.

All student of Politeknik Pos Indonesia receiving the logistic course (minimally introductionary of logistic course for the department aside from business logistic) to a total of \pm 360 students for one generation were regarded as the population.

The use of SEM would require a large samples. According to Hair (2006), the sample size for model testing where SEM was applied varied between 100-200 samples or depended on all latent variales (i.e. parameter numbe rmultiplied with 5 to 10). Therefore, number of sample to a total of 162 was generally accepted as representative sample in SEM analysis, and so the sample size to a total of 162 persons (users) were taken for the implementation of supply chain simulator application. The aim of supply chain simulator application was in give user experience (UX) related to bullwhip effect showing the logistic area related to distribution. This means that every user who makes use of suppl chain simulator application has the basic principle of logistic.

Determination of UX variable in TAM for the application of supply chain simulator. In this research the most relevant Journal published by Zacharis, 2012 was prepared. The reason was due to the indicator could still be developed and be added with new construction (for instance the student participation adpoted by Sheng and Zolfagharian, 2014). Therefore, the proposed model in this research is given figure 3 .

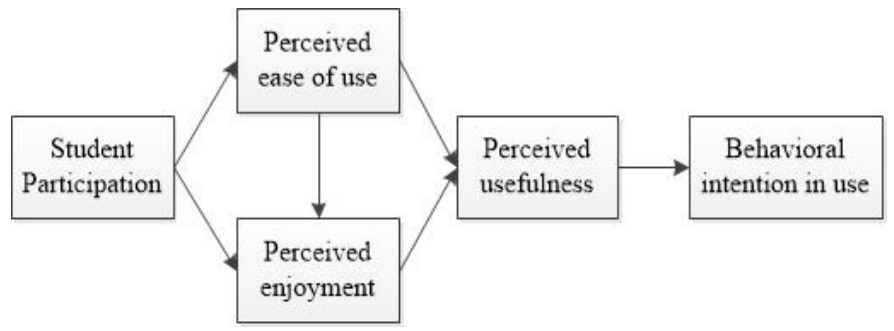

Figure 3 - TAM Model of Supply Chain Simulator

The resuld of research indicated that the expected experience by the user after the application of simulator has been used in connection with three matters:

- Life goals: every player obtained experience to the determination of order strategy to solve the happening bullwhip effect;

- Experience goals: every player obtained experience in conducting his role either as retailer/distributor/ wholesalerfactory. Therefore the player would feel the existace of bullwhip effect and how the above bullwhip effect could be solved;

- End goals: every player could understand what kind of matter which case the happening bullwhip effect, what to be done if happend and how to use the equipment/method to order to avoid the existance of above bullwhip effect;

If related with TAM variable, UX variable is related with student participation for achieving life goals, experience goals and end goals which give rise to the following measurement variables:

- Usefullness Variables: Usefullnes Variables use the instrument developed by Davis (1989); Hsu and Lu (2004), later on modified in context with the use of the simulation application of supply chain simulator provided with three question items;

- Ease of Use Variables: Ease of Use Variables use the instrument developed by Davis (1989); Hsu and Lu (2003), later on modified in context with the use of simulation application of supply chain simulator provided with four question items; 
- Interest/Motivation variables: interest/ Motivation Variables use the application simulation of supply chain simulator with two items as developed by Davis (1989), Hsu and Lu (2003), later on modified to context with the use of application simulation of supply chain simulator variable in intention variable of use and enjoyment variable;

- User Experience Variables: User Experience Variables in this research is included in student participation.

Based on above mentioned variables, then the following question are given:

Table 1 - Questions from mesasurement variables TAM

\begin{tabular}{|l|l|}
\hline No & \multicolumn{2}{|c|}{ Questions } \\
\hline Student Participation \\
\hline 1 & the use of supply chain simulator application, information has triggering action the other users \\
\hline 2 & $\begin{array}{l}\text { The effect of supply chain simulator application againsta the game which is running (bullwhip effect arises or } \\
\text { not) }\end{array}$ \\
\hline 3 & The number of actions performed when the supply chain simulator application was used \\
\hline 4 & $\begin{array}{l}\text { The amount of time spent in the supply chain simulator application, from start to finish, and then the ranking } \\
\text { list is displayed }\end{array}$ \\
\hline Perceived Ease of Use \\
\hline 1 & The ease in playing the supply chain simulator application \\
\hline 2 & The level of simplicity of using the supply chain simulator application \\
\hline 3 & The ease in learning the supply chain simulator application \\
\hline 4 & The ease in understanding the working of supply chain simulator application \\
\hline Perceived Enjoyment \\
\hline 1 & I found the interesting experience in learning of bullwhip effect in supply chain simulator application \\
\hline 2 & The supply chain simulator application can be a fun learning tool \\
\hline 3 & Feel very happy (not bored) when using the supply chain simulator application \\
\hline Perceived Usefulness \\
\hline 1 & The supply chain simulator application increased my understanding of the supply chain \\
\hline 2 & The supply chain simulator application hels facilitate the learning process supply chain \\
\hline 3 & The supply chain simulator application helps in learning how bullwhip effect arises in a supply chain process \\
\hline Behavioral Intention to Use \\
\hline 1 & You will recommended the application as a learning tool about the bullwhip effect \\
\hline 2 & Selection of the supply chain simulator application after getting the relevant theory \\
\hline 3 & $\begin{array}{l}\text { Reuse of the supply chain simulator application, if you want to understand the issues related to the bullwhip } \\
\text { effect }\end{array}$ \\
\hline
\end{tabular}

Implementation of Supply Chain Simulation. Implementation of supply chain application simulator use was applied in the form of game on 162 respondents/users cariend out in the Politeknik Pos Indonesia. At the time of above mentioned supply chain simulation application all respndents were carried out manually. Based on the reults of simulation observation carried out on respondents, the conventional simulation:

- Requires several training and direction, because many respondents do not understand why they must write the demand of goods;

- Many respondents must remove and rewrite the demand value of goods several times after the papers of gods demand are submitted to the previous chains;

- Part of the respndent seems to be bored (not enthusiastic) by writing the figure of goods demand perfunctorily (very high gape with the previous demand).

Measurement of TAM Model on Supply Chain Simulator:

Table 2 - Loading Factor Value of Student Participation (SP) Variable

\begin{tabular}{|c|c|c|c|}
\hline Indicator variables & Loading Factor & P-value & Remarks \\
\hline SP1 $\leftarrow S P$ & 0.832 & 0.000 & VALID \\
\hline SP2 $\leftarrow S P$ & 0.884 & 0.000 & VALID \\
\hline SP3 $\leftarrow S P$ & 0.835 & 0.000 & VALID \\
\hline SP4 $\leftarrow S P$ & 0.856 & 0.000 & VALID \\
\hline
\end{tabular}

It can be concluded that the fourth indicator variables measurig the Student Participation latent variable were regarded as valid variable. 
The result of coputation of Contruct Reliability (CR) value are as follows:

$$
C R=\frac{\left(\sum_{i=1}^{n} \lambda_{i}\right)^{2}}{\left|\left(\sum_{i=1}^{n} \lambda_{i}\right)^{2}+\left(\sum_{i=1}^{n} \delta_{i}\right)\right|}=\frac{(3.047)^{2}}{\left[(3.047)^{2}+(1.095)\right]}=0.894^{*}
$$

It can be concluded that all indicators arranging the Student Participation latent variable was reliable.

Table 3 - Loading Factor Value of Perceived Ease of Use (PEU) Variable

\begin{tabular}{|c|c|c|c|}
\hline Indicator variables & Loading Factor & P-value & Remarks \\
\hline PEU1 $\leftarrow P E U$ & 0.755 & 0.000 & VALID \\
\hline PEU2 $\leftarrow P E U$ & 0.860 & 0.000 & VALID \\
\hline PEU3 $\leftarrow P E U$ & 0.916 & 0.000 & VALID \\
\hline PEU4 $\leftarrow P E U$ & 0.870 & 0.000 & VALID \\
\hline
\end{tabular}

It can be concluded that the fourth indicator variables measurig the Perceived Ease of Use latent variable were regarded as valid variable.

The result of coputation of Contruct Reliability (CR) Value are as follows:

$$
C R=\frac{\left(\sum_{i=1}^{n} \lambda_{i}\right)^{2}}{\left[\left(\sum_{i=1}^{n} \lambda_{i}\right)^{2}+\left(\sum_{i=1}^{n} \delta_{i}\right)\right]}=\frac{(3.401)^{2}}{\left[(3.401)^{2}+(1.094)\right]}=0.913^{*}
$$

It can be concluded that all indicators arranging the Perceived Ease of Use latent variable was reliable.

Table 4 - Loading Factor Value of Perceived Enjoyment (PE) Variable

\begin{tabular}{|c|c|c|c|}
\hline Indicator variables & Loading Factor & P-value & Remarks \\
\hline $\mathrm{PE} 1 \leftarrow P E$ & 0.914 & 0.000 & VALID \\
\hline $\mathrm{PE} 2 \leftarrow P E$ & 0.111 & $>0.05$ & LESS VALID \\
\hline $\mathrm{PE} 3 \leftarrow P E$ & 0.217 & $>0.05$ & LESS VALID \\
\hline
\end{tabular}

It can be concluded that there was a less valid indicator in mesuring the Perceived Enjoyment latent variable. However, for the perfect of determined research model, the above mentioned indicator would remain be used in Structural Equation Modeling (SEM).

The result of coputation of Contruct Reliability (CR) Value are as follows:

$$
C R=\frac{\left(\sum_{i=1}^{n} \lambda_{i}\right)^{2}}{\left[\left(\sum_{i=1}^{n} \lambda_{i}\right)^{2}+\left(\sum_{i=1}^{n} \delta_{i}\right)\right]}=\frac{(1.242)^{2}}{\left[(1.242)^{2}+(2.105)\right]}=0.423^{*}
$$

It can be concluded that the indicator in mesuring the Perceived Enjoyment latent variable was less reliable. However, this variable would remain be maintained in this research model.

Table 5 - Loading Factor Value of Perceived Usefulness (PU) Variable

\begin{tabular}{|c|c|c|c|}
\hline Indicator variables & Loading Factor & P-value & Remarks \\
\hline PE1 $\leftarrow P U$ & 0.830 & 0.000 & VALID \\
\hline PE2 $\leftarrow P U$ & 0.953 & 0.000 & VALID \\
\hline PE3 $\leftarrow P U$ & 0.940 & 0.000 & VALID \\
\hline
\end{tabular}

It can be concluded that the fourth indicator variables measurig the Perceived Usefulness latent variable were regarded as valid variable.

The result of coputation of Contruct Reliability (CR) value are as follows:

$$
C R=\frac{\left(\sum_{i=1}^{n} \lambda_{i}\right)^{2}}{\left[\left(\sum_{i=1}^{n} \lambda_{i}\right)^{2}+\left(\sum_{i=1}^{n} \delta_{i}\right)\right]}=\frac{(2.723)^{2}}{\left[(2.723)^{2}+(0.519)\right]}=0.934^{*}
$$


It can be concluded that all indicators arranging the Perceived Usefulness latent variable was reliable.

Table 6 - Loading Factor Value of Behavioral Intention of Use (BIU) Variable

\begin{tabular}{|c|c|c|c|}
\hline Indicator variables & Loading Factor & P-value & Remarks \\
\hline BIU1 $\leftarrow B I U$ & 0.890 & 0.000 & VALID \\
\hline BIU2 $\leftarrow B I U$ & 0.857 & 0.000 & VALID \\
\hline BIU3 $\leftarrow B I U$ & 0.816 & 0.000 & VALID \\
\hline
\end{tabular}

It can be concluded that the fourth indicator variables measurig the Behavioral Intention to Use latent variable were regarded as valid variable

The result of coputation of Contruct Reliability (CR) Value are as follows:

$$
C R=\frac{\left(\sum_{i=1}^{n} \lambda_{i}\right)^{2}}{\left|\left(\sum_{i=1}^{n} \lambda_{i}\right)^{2}+\left(\sum_{i=1}^{n} \delta_{i}\right)\right|}=\frac{(2.563)^{2}}{\left[(2.563)^{2}+(0.807)\right]}=0.890^{*}
$$

It can be concluded that all indicators arranging the Behavioral Intention to Use latent variable were reliable

Structural Equation Modelling (SEM):

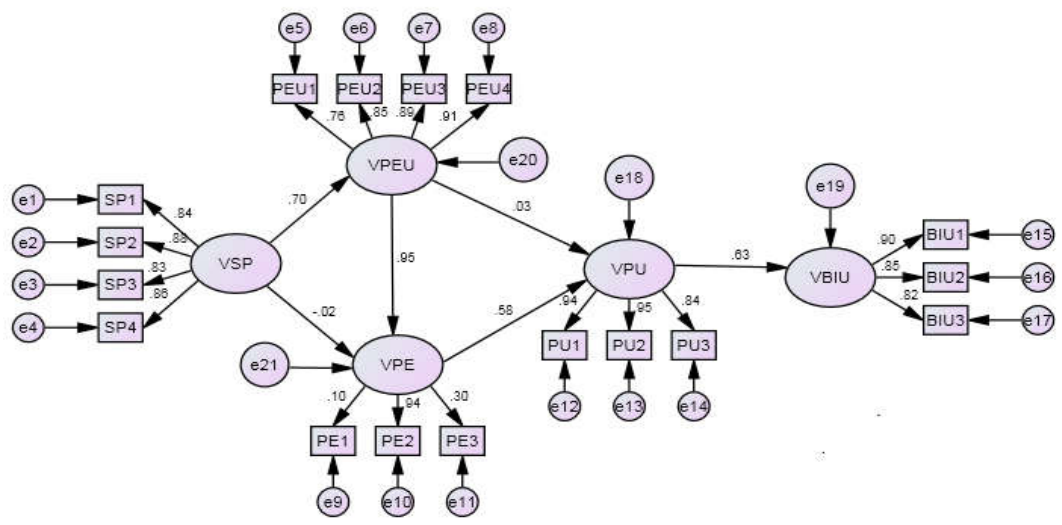

Direct Affect. The size of direct effect can be seen from loading factor or from the value of standardized direct effects as shown in Appendix. Mean while, direct effect of independent variable based on the research model is shown in Table 7.

Table 7 - Direct Effect of Variable in Research

\begin{tabular}{|c|c|c|c|}
\hline Indicator Variables & Effect Size & P-value $^{*}$ & Remarks \\
\hline $\mathrm{PU} \leftarrow S P$ & 0.389 & 0.733 & Positive, not significant \\
\hline $\mathrm{PE} \leftarrow S P$ & 0.657 & 0.000 & Positive, significant \\
\hline $\mathrm{PU} \leftarrow P E U$ & 0.550 & 0.047 & Positive, significant \\
\hline BIU $\leftarrow P E U$ & 0.363 & 0.915 & Positive, not significant \\
\hline BIU $\leftarrow P E$ & 0.363 & 0.042 & Positive, significant \\
\hline
\end{tabular}

Indirect Affect. The size of indirect effect can be seen from loading factor or from the value of standardized indirect effects as shown in Appendix. Mean while, direct effect of independent variable based on the research model is shown in Table 8.

Table 8 - Indirect Effect of Variable in Research

\begin{tabular}{|c|c|c|c|}
\hline Indicator Variables & Effect Size & P-value & Remarks \\
\hline PEU $\leftarrow S P$ & 0.695 & 0.000 & Positive, significant \\
\hline PE $\leftarrow S P$ & -0.024 & 0.739 & Negative, not significant \\
\hline $\mathrm{PE} \leftarrow P E U$ & 0.945 & 0.000 & Positive, significant \\
\hline $\mathrm{PU} \leftarrow P E U$ & 0.029 & 0.916 & Positive, not significant \\
\hline $\mathrm{PU} \leftarrow P E$ & 0.582 & 0.036 & Positive, significant \\
\hline BIU $\leftarrow P U$ & 0.626 & 0.000 & Positive, significant \\
\hline
\end{tabular}




\section{CONCLUSION AND RECOMMENDATIONS}

Based above mention discusstion, it can be concluded that:

The user acceptance on supply chain simulator are as folows: directly affected (positive and significant) by perceived usefulness when supply chain application simulator is used; indirectly affected (positive but insignificant) by perceived ease of use when supply chain application simulator is used; indirectly affected (positive andt significant) by perceived enjoyment of use when supply chain application simulator is used.

The application of supply chain simulator gives an easiness in learning the bullwhip effect in supply chain. User experience when this application is used will directly affect on perceived ease of use, which later on will directly affect on perceived enjoyment, and at last it will positively and significantly affect on behavioral intention to use (the desire for recommending and using the application of supply chain simulator).

The use of supply chain simulator application will make the respondent easier to understand the meaning and kind of simulation that will be undertaken through the play role included in the application.

Based on above research result, it can be recommended:

- To determine this application as part of supply chain learning process in the class, because it will stimulate the user in the application of supply chain strategy and to see the effect on the performnce of the whole supply chain;

- To develop this application simulator towards the multy chains

\section{ACKNOWLEDGMENTS}

We would like to express our gratitude to Ristek Dikti for funding grant to complete presented research.

\section{REFERENCES}

1. Chin Lung Hsu., Hsi-Peng Lu.Why do people play on-line games? An extended TAM with social influences and flow experience, Information \& Management 41 (2004) 853-868

2. Davis, F. D. "Perceived usefulness, perceived ease of use, and user acceptance of information technology", MIS Quarterly. 1989. 319-340, doi:10.2307/249008.

3. Hsu, Chin-Lung, Lu, Hsi-Peng. Why do people play on-line games? An extended TAM with social influences and flow experience, Information \& Management 41. 2004. 853.

4. Indrajit, Eko Richardus., Konsep Manajemen Supply Chain., Gramedia widiasarana Indonesia. 2002.

5. Kaminsk., P. \& Simchi, D., A New Computerized Beer Game: A Tool for Teaching the Value of Integrated Supply Chain Management, Northwestern University Production and Logistics Laboratory \& Department of Industrial Engineering and Management Sciences. 2007.

6. Lee H.L., Padmanabhan V., Whang S., The Bullwhip Effect in Supply Chains. Sloan Management Review. 1997.

7. Leslie StoelKyu Hye Lee."Modeling the effect of experience on student acceptance of Web-based courseware", Internet Research, 2003. Vol. 13 Iss 5 pp. $364-374$.

8. Linda G. Wallace., Steven D. Sheetz. The adoption of software measures: A technology acceptance model (TAM) perspective, Information \& Management 51.2014. 249-259.

9. Mulyati E., Hamidin, D., Fauzan, M.N., 2014, Perancangan Model Simulator Rantai Pasok, Seminar Nasional Teknologi Informasi XI Tahun 2014, Universitas Tarumanegara.

10. Nick Z. Zacharis. "Predicting college students' acceptance of podcasting as a learning tool", Interactive Technology and Smart Education, 2012. Vol. 9 Iss 3 pp. 171 - 183.

11. Sauvé1 L., Renaud L., Kaufman D., Marquis JS., Distinguishing between games and simulations: A systematic review, Educational Technology \& Society. 2007. 
12. Senge, The fifth discipline: The art and practice of the learning organization, New York. 1990.

13. Sterman, J.D., Instructions for Running the Beer Distribution Game (D-3679), Sloan School of Management, MIT. 1984.

14. Timothy Teo Ömer Faruk Ursava\# Ekrem Bahçekapili, "Efficiency of the technology acceptance model to explain pre-service teachers' intention to use technology", CampusWide Information Systems, 2012. Vol. 28 Iss 2 pp. 93 - 101.

15. Venkatesh, V.; Morris, M. G.; Davis, G. B.; Davis, F. D. "User acceptance of information technology: Toward a unified view" (PDF), MIS Quarterly, 2003. 425-478

16. Wiegers, Software Requirements, 2nd ed., Microsoft Press, 2003Lee H.L., Padmanabhan V., Whang S., The Bullwhip Effect in Supply Chains. Sloan Management Review. 1997.

17. Xiaojing Sheng Mohammadali Zolfagharian. "Consumer participation in online product recommendation services: augmenting the technology acceptance model", Journal of Services Marketing, 2014. Vol. 28 Iss 6 pp. $460-470$. 